\title{
PRINCIPLES OF CONSTRUCTING A PSYCHOREHABILITATION PROGRAM IN PATIENTS OF SURGICAL HOSPITAL SUFFERING FROM NEUROTIC DISORDERS AT THE PRE AND POSTOPERATIVE STAGES OF TREATMENT
}

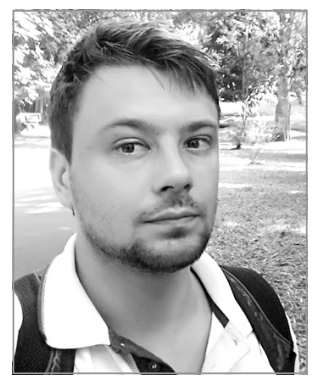

D. I. Dimshitc (c) Dmytro Dimshitc (Ukraine) - Assistant Professor of the Department of Psychiatry, Narcology, Neurology and Medical Psychology of V. N. Karazin Kharkiv National University, Northern Building, 6 Svobody Square, Kharkiv, 61077; e-mail: dimshitc@gmail.com; 0RCID:0000-0001-9869-2663

(с) Димшиць Дмитро Ігоревич (Україна) - асистент кафедри психіатрії, наркології, неврології та медичної психології Харківського національного університету імені В.Н. Каразіна, офіс 607, Північний корпус, пл. Свободи, 6, м. Харків, 61077, e-mail: dimshitc@gmail.com; 0RCID: 0000-0001-9869-2663.

(c) Дымшиц Дмитрий Игоревич (Украина) - ассистент кафедры психиатрии, наркологии, неврологии и медицинской психологии Харьковского национального университета имени В. Н. Каразина, офис 607, Северный корпус, пл. Свободы, 6, г. Харьков, 61077; е e-mail: dimshitc@gmail.com; ORCID: 0000-0001-9869-2663.

№ 9, 2018, p. 135-141

PRINCIPLES OF CONSTRUCTING A PSYCHOREHABILITATION PROGRAM IN PATIENTS OF SURGICAL HOSPITAL SUFFERING FROM NEUROTIC DISORDERS AT THE PRE AND POSTOPERATIVE STAGES OF TREATMENT

Abstract.

Taking into account the tasks set, the main goal of the study was to develop and approve a short-term effective psychotherapeutic program that could be easily implemented both in the surgical hospital and in the outpatient settings for the provision of surgical medical care. It should take into account the individual approach in the treatment program for patients with gastroenterological profile with the presence of neurotic disorders. In the course of our work, we sought to use modern psychotherapeutic strategies based on the principles of integrativity, leading to a reduction in the duration of intervention and a reduction in material costs without reducing the ultimate effectiveness of psychotherapeutic correction. Among the many available methods of psychotherapeutic intervention, we selected those techniques and methods that could be freely adapted for inpatient conditions, taking into account factors that may impede the conduct of psychotherapeutic effects in a surgical hospital. Taking into account the biopsychosocial development model, both neurotic disorders and psychosomatic diseases, it is necessary to use psychopharmacological, psychotherapeutic, social methods in the structure of psychosocial rehabilitation of this cohort of patients. We have developed a psycho-rehabilitation program, created on the basis of personality-oriented, cognitive techniques and neuro-linguistic programming, which allows us to conduct a psycho-rehabilitation on the basis of a surgical hospital in a short time. The use of this program will prevent the development of protracted forms of nonpsychotic mental disorders (and, ultimately, the development of personality deformation), as well as improve the prognosis of somatic illness. At the same time, we reduced drug treatment to a minimum due to the need for oral administration of psychotropic drugs against the background of a disease of the gastrointestinal tract.

Key words: neurotic disorders, gastroenterological disorders, psycho-rehabilitation program, psychotherapy, psychopharmacotherapy.

ПРИНЦИПЫ ПОСТРОЕНИЯ ПРОГРАММЫ ПСИХОРЕАБИЛИТАЦИИ У ПАЦИЕНТОВ ХИРУРГИЧЕСКОГО СТАЦИОНАРА, СТРАДАЮЩИХ НЕВРОТИЧЕСКИМИ НАРУШЕНИЯМИ НА ПРЕДВАРИТЕЛЬНОМ И ПОСТОПЕРАЦИОННОМ ЭТАПАХ ЛЕЧЕНИЯ

Аннотация.

С учетом поставленных задач, основная цель проведенного исследования заключалась в разработке и утверждении краткосрочной эффективной психотерапевтической программы, которая легко бы реализовалась как в условиях хирургического стационара так и в амбулаторных условиях оказания хирургической медицинской помощи с учетом индивидуального подхода в программе лечения пациентов гастроэнтерологического профиля с наличием невротических расстройств. В процессе работы мы стремились использовать современные психотерапевтические стратегии, основанные на принципах интегративности, ведущей к снижению сроков вмешательства и уменьшения материальных расходов без снижения конечной эффективности психо- 
терапевтической коррекции. Среди многих имеющихся методов психотерапевтического вмешательства мы подбирали те методики и методы, которые можно было бы свободно адаптировать для стационарных условий, с учетом факторов, которые могут препятствовать проведению психотерапевтического воздействия в условиях хирургической больницы. С учетом биопсихосоциальной модели развития, как невротических расстройств, так и психосоматических заболеваний, необходимо использование психофармакологических, психотерапевтических, социальных методов в структуре психосоциальной реабилитации этого контингента больных. Нами разработана психореабилитационная программа, созданная на основе личностноориентированных, когнитивных техник и нейролингвистического программирования, что позволяет в сжатые сроки провести психореабилитацию на базе хирургического стационара. Использование данной программы позволит предупредить развитие затяжних форм непсихотических психических расстройств (и, в конечном счёте, развитие деформации личности), а так же улучшает прогноз соматического заболевания. При этом, медикаментозное лечение мы свели к минимуму из-за необходимости перорального приема психотропных препаратов на фоне заболевания желудочно-кишечного тракта.

Ключевые слова: невротические расстройства, гастроэнтерологические расстройства, психореабилитационная программа, психотерапия, психофармакотерапия.

ПРИНЦИПИ ПОБУДОВИ ПРОГРАМИ ПСИХОРЕАБІЛІТАЦІЇ У ПАЦІЕНТІВ ХІРУРГІЧНОГО СТАЦІОНАРУ, ЩО МАЮТЬ НЕВРОТИЧНІ ПОРУШЕННЯ НА ПОПЕРЕДНЬОМУ ТА ПІСЛЯОПЕРАЦИЙОМУ ЕТАПАХ ЛІКУВАННЯ

Анотація.

З урахуванням поставлених завдань, основна мета проведеного дослідження полягала в розробці та затвердженні короткострокової ефективної психотерапевтичної програми, яка легко 6 реалізувалася як в умовах хірургічного стаціонару так і в амбулаторних умовах надання хірургічної медичної допомоги з урахуванням індивідуального підходу в програмі лікування пацієнтів гастроентерологічного профілю з наявністю невротичних розладів. У процесі роботи ми прагнули використовувати сучасні психотерапевтичні стратегії, засновані на принципах інтегративності, що зумовить зниження термінів втручання і зменшення матеріальних витрат без зниження кінцевої ефективності психотерапевтичної корекції. Серед багатьох наявних методів психотерапевтичного втручання ми підбирали ті методики та методи, які можна було б вільно адаптувати для стаціонарних умов, з урахуванням факторів, які можуть перешкоджати проведенню психотерапевтичного впливу в умовах хірургічної лікарні. 3 урахуванням біопсихосоціальної моделі розвитку, як невротичних розладів, так і психосоматичних захворювань, необхідно використання психофармакологічних, психотерапевтичних, соціальних методів в структурі психосоціальної реабілітації цього контингенту хворих. Нами розроблена психореабілітаційні програма, створена на основі особистоорієнтованих, когнітивних технік і нейролінгвістичного програмування, що дозволяє в стислі терміни провести психореабілітацію на базі хірургічного стаціонару. Використання даної програми дозволить попередити розвиток затяжних форм непсихотичних психічних розладів (i, в кінцевому результаті, розвиток деформації особистості), і так само покращує прогноз соматичного захворювання. При цьому медикаментозне лікування ми звели до мінімуму через необхідність перорального прийому психотропних препаратів на тлі захворювання шлунково-кишкового тракту.

Ключові слова: невротичні розлади, гастроентерологічні розлади, психореабілітаційні програми, психотерапія, психофармакотерапія.

Pathogenetic psychotherapy of psychogenies that developed in the conditions of occurrence (exacerbation) of the gastrointestinal tract disorders, at the pre and postoperative stages of treatment, is the main method of treatment and is aimed at re-forming the personality relations, replacing inadequate relationships with adequate ones[1-5].The use of standard psychotherapeutic techniques in conditions of treatment in a surgical hospital is not effective enough and is not always applicable. For the correction of ND (neurotic disorders) in patients with gastroenterological profile, it is advisable to use a special psychotherapeutic system [6-9].

Based on the analysis of the processes of disadaptation and the characteristics of the symptomatology, reflecting the inadequacy of the relationship, it is necessary to carry out correction of excessive subjectivity, teaching the objective method of assessing its somatic state, possible complications, prognosis, treatment tactics [10-13].

Taking into account the tasks set, the aim of the research was to develop and approve a short-term effective and non-energydifferentiated psychotherapeutic program that is easily implemented both in a surgical hospital and outpatient medical care and oriented to individual work with gastroenterological patients suffering from ND. We sought to use modern psychotherapeutic strategies based on the principles of integrative and leading to short-term and material costs without reducing efficiency. From the numerous principles of modern psychotherapy, short-term is one of the main, ensuring patients from developing 
a "psychotherapeutic defect or addiction", "escaping to psychotherapy", and shifting responsibility for one's life to a psychotherapist [14-17].

The use of personal-centered psychotherapeutic methods of domestic and world psychotherapy, in our opinion, allows us to cover the most important aspects of ND most fully and pathogenetically. Of the many types of psychotherapy, we sought to select those methods and techniques that can be adapted in a physical hospital environment, while taking into account the factors that prevent the group forms of psychotherapy in a surgical hospital. Such unfavorable factors include:

1. Impossibility of public discussion of personal problems due to microsocial features of communication;

2. Individuality (specificity) of the problem that led to the development of a physical illness, a variety of forms of neurotic behavior;

3. The lack of time and the specific features of the surgical hospital.

Proceeding from the above, we have placed emphasis on the use of individual psychotherapy. In choosing psychotherapeutic techniques, the most important, in our opinion, is the clinical approach, taking into account the severity, the structure of the neurotic disorder and the possibility of a multi-level therapeutic effect.The main goal of the therapy was not only a change in the disease state and the relief of neurotic symptoms, but also the restoration of disturbed personality relationships.

Taking into account the specifics of the surgical hospital, they were guided by the principles aimed at the fastest rehabilitation of patients, combining the sequence of the following provisions:

unity of psychosocial and biological methods of influence;

multiplicity of efforts being made to various areas and flexibility in the application of basic psychotherapeutic techniques;

- partnership, involving the patient himself in the implementation of therapeutic effects.

The general principle of constructing psychotherapy in patients of gastroenterological profile is, in our opinion, a differentiated combination of symptomatic, personalityoriented and social-centered psychotherapy. Accordingly, for the correction of ND in patients of gastroenterological profile, in our opinion, it is advisable to use the following types of psychotherapy:

1) rational and cognitive, aimed at the formation of an adequate assessment of a physical illness, possible complications, prognosis, understanding of the tactics of its treatment and rehabilitation;

2) personality-oriented (reconstructive) psychotherapy, which helps to fully cover the cause-effect relationship of ND;

3) "Ericksonian hypnotherapy", which by means of "adjustment and maintenance"makes it possible to facilitate the achievement of the trance state bypassing the conscious stereotypical neurotic modes of reaction;

4) the methodical methods of NLP ("anchoring", etc.), contributing in the shortest possible time, changing the submodality of perception, improving health, reducing the degree of destructive effect of intensive nosogenic factors, changing them to neutral or positive and thus preventing the growth of neurotic symptoms;

5) teaching of methods autogenic training and autosuggestion [19-24].

Preceded by therapy, the study and analysis of data obtained during the study: the severity and significance of psychotraumatic factors, level of expression and structure of neurotic symptoms; the personal characteristics of the patient, which allowed to determine the optimal approaches for psychotherapy.

The task of short-term hospital stay (about 5-10 days) was set with subsequent psychocorrective measures (if necessary) in outpatient settings.

While carrying out psychotherapeutic treatment, the main criteria for its evaluation were considered: efficiency and quality of the techniques used in the treatment process, simplicity and accessibility techniques, the treatment time.

Numerous studies have proven the effectiveness of nondirective methods of psychotherapy. Therefore, the main emphasis in the psychotherapeutic process was made by us on receptions of nondirective suggestion with elements of (NLP). NLP was used to simulate a psychotraumatic situation, to achieve comfortable (resource) conditions, to change the negative state of health to the opposite. The use of NLP techniques in teaching Autogenic training and autosuggestion is already in the first stages allowed to notice a significant positive dynamics, manifested by a decrease in complaints, psychoemotional stress, irritability, weakness and improvement of sleep. This allowed for the next stages, to achieve a rapid reduction of neurotic symptoms, reducing the duration of therapy.

Treatment was carried out in stages and consisted of three stages. Each patient underwent 5-6 individual sessions. The duration of each session was about 50-60 minutes. 
Much attention was paid to the availability of information received by patients, the setting of feasible tasks for them, the systematic approach to mastering the skills of expressive therapy.

The first stage was preparatory. Its main goal was to establish a confidential contact with the doctor, create motivation for treatment and participation in the therapy process, relieve psychoemotional stress, anxiety before the sessions. Given the high level of anxiety, emotional excitability and irritability, increased, in most cases, suggestibility caused by asthenization against the background, as a rule, initially low readiness for joint active psychotherapeutic work, a certain sequence of psychocorrectional measures was developed.

At the first meeting with the patient, we were striving for minimal activity, nondirectivity, which contributed to the sincere disclosure of his emotional experiences, the creation of a confidential contact (the stage of "adjustment"). Then, we increased our activity, proceeding to clarify the "internal picture of the disease" and verbalize the patient's ideas about the disease, the expectations from the treatment and the prospects for recovery. Mutual relations with the patient deepened, we became an assistant in the work of his/her inner world, explanatory (cognitive) and rational psychotherapy was used. At this stage, the therapeutic-patient contact was established on emotional and cognitive levels using verbal and non-verbal communication techniques, using the techniques of NLP widely.

Psychodiagnostic scales were used to determine the severity of the disorders and subsequent dynamic changes in the treatment process. In the form of an individual conversation, the main neurotic disorders were diagnosed. The "model of perception" of the patient was studied, "adjustment" and "synchronization" to this model were carried out. Next, the technique of "anchoring" was used to identify the fixed kinesthetic unconscious indicators of stress, which were the cause of the development of the neurotic state, that is, the psychotraumatic situation was simulated with its conditioned reflex anchoring.

The application of the "anchoring" technique allowed to change the negative experience quite efficiently and quickly to the desired one. We found the "keys" of a painful reaction to the psychotraumatic situation and carried out their unlocking. After that, attempts to cause the initial negative "anchor" remained unanswered, "neutral." This procedure for neutralizing kinesthetically anchored "anchors" was the final phase of the first stage. During this stage, the dominant psychotherapeutic impact was the harmonious combination of NLP with rational and cognitive psychotherapy. The first stage consisted of one session lasting from 60 to 90 minutes.

Atthesecond stage, themain medical effect was performed. The principles of personality-oriented psychotherapy were applied to the techniques applied in the first stage. In the methods of NLP, if necessary, techniques of "triple dissociation," the creation of a "positive image of oneself," etc. were added. Over the course of two or three sessions, the use of the "anchoring" method helped to reliably and securely consolidate the comfortable ("resource") state for the rapid achievement, in the subsequent, of a multilevel "trance". This was important, as it helped, if necessary, to bring about a "resource state". The application of the methods of NLP and Erickson's hypnosis for "adjustment" to the unconscious methods of response greatly facilitated and accelerated the achievement of a multilevel "trance," helped to reliably "plunge". At this stage, the main treatment load was starting to perform "trance states".

Having adjusted to the patient's current experiences, "his world models," carried out "immersion in trance", all the time carefully reacting to the patient's current state and continuing to adjust to the reactions of this behavior. With the deepening of the "trance" in an indirect form, the cause-effect relationships between the neurotic symptoms and the characteristics of the personal response were explained. Influenced emotional, intellectual, sensory and motivational levels of conflict reflection. The aim was to understand the patient causal relationship between neurotic symptoms and the characteristics of a personal response, bypassing the conscious "limiting stereotypes of behavior". At this stage, correction of inadequate reactions and behavioral forms was carried out, an understanding of the causes and mechanisms of the development of the disorder was achieved, the disturbed relationships were changing, and new forms of emotional and behavioral response were being developed.

In the third and final stage, the goal was to consolidate the therapeutic result achieved in the previous stage. Considerable attention was paid to auto-training and autosuggestion. Methods of autogenous neutralization were used: autogenous response and Autogenic verbalization. To neutralize negative experiences, the methods of repetition of those situations, which were the cause of the trauma, were used. Autologous verbalization was carried out with closed eyes, and the patient's task was to tell about all sensory images appearing in the state of Autogenic relaxation. Unlike autogenous 
response, autologous verbalization was used in those cases when the interfering material could be accurately described. The verbalization of a certain topic (aggression, fear, desire) was carried out in a state of Autogenic relaxation and continued until the patient stated that he had nothing to say. The possibility of a curative effect is largely determined by the fact that these methods are inherently trance (or trance during their development develops as a concomitant state). It is impossible not to mention the mechanism of placebo, which works if a person believes in a therapist, or the technique used by him. In fact, the above-mentioned autotraining can be considered as a modification of the technique of hypnosis, conducted indirectly through psychosomatic symptoms. The general rule with this approach was that the figurative context could be very different, the most important thing is the adjustment through it to the symptoms with their subsequent virtual destruction.

Summarizing the strategy of interaction with the patient during psychotherapy, the following sequence of actions can be noted. At the first meeting, we were striving for minimal activity, non-directs, which contributed to the sincere disclosure of his emotional experiences, the creation of a confidential contact. Then, we increased our activity, proceeding to clarify the "internal picture of the disease" and verbalize his ideas about it, the expectations of treatment and the prospects for recovery. Carrying out the correction, discussed with him the data of psychological and somatic examinations, explaining that the causes of neurotic disorders lie not in organic changes in the body and real life situations, but in inadequate reactions to them. At the moment, we acted as an expert, providing the patient with relevant information, and after understanding the connection between symptomatology and provocative situations, the content of the conversations began to change.

The subject of discussion was no symptoms, but psychological problems and experiences. A certain scheme of development of his illness was built up in the patient's mind (emotional factors and pathogenic situation - personal position and attitudes - needs and motives neurotic conflict - somatic symptoms - neurotic symptoms - neurotic (nonadaptive) behavior aggravation of somatic disorders). Relations with the patient deepened, we became an assistant in the work of his inner world. At the final stage, we again increased our activity and even directness in testing and fixing the patient new ways of perception, emotional response and behavior.

During the treatment course, at all its stages, two interrelated psychological processes were constantly carried out: awareness and reconstruction of the personality relations. The first process - awareness, insight - consisted in the gradual expansion of the patient's self-awareness, connected with the need to understand the true sources of his own somatic and neurotic disorders; the second the reconstruction of personal relations - in accordance with the degree of awareness, there was a correction of the disturbed and the development of new relationships at the cognitive and behavioral levels.

During the treatment course, at all its stages, two interrelated psychological processes were constantly carried out: awareness and reconstruction of the personality relations. The first process - awareness, insight - consisted in the gradual expansion of the patient's self-awareness, connected with the need to understand the true sources of his own somatic and neurotic disorders; the second - the reconstruction of personal relation - in accordance with the degree of awareness, there was a correction of the disturbed and the development of new relationships at the cognitive and behavioral levels.

The most significant and difficult part of the discussion was to help the patient understand that his neurotic symptoms and organic disease of the gastrointestinal tract were caused not only and not so much by the circumstances of life and external conflicts, but also by an internal conflict based on his inadequate relations and incompatible needs, as a result of which he is not able to solve his problems. The conflict was accompanied by emotional tension, disorganizing somato-neuro-mental functioning and causing somatic disease.

Clarifying the psychological mechanisms of the disease is not a purely rational, cognitive process; it is necessary to involve deep, unconscious parties and stereotypes of personal reaction; so we engaged in quite significant emotional and mental experiences, which made possible the necessary restructuring of the individual on the basis of positive internal resources. Rational, intellectual understanding of neurotic problems and their causes, the conditionality of the emergence (exacerbation) of a physical illness by psychological factors in itself is of little effect and does not lead to necessary (therapeutic) changes in the personality of the patient; it must be the final link in the process of awareness, emotionally saturated in its essence.

The depth of awareness has been often multilevel. The first level concerned the understanding of the maladaptive behavior in a pathogenic (nosogenic) situation. The second level reflected the comprehension of those 
inadequate attitudes (in self-esteem, attitude to other people and the surrounding world) that underlie his neurotic symptoms and physical illness. The third level of understanding of the genesis of neurotic disorders is associated with awareness of violations in the sphere of the motives and needs underlying the improperly formed relationships of the individual.

Awareness and understanding are only the beginning of psychotherapy, or rather, its condition. It is important to reorganize those important personal relations in this situation, the disruptive influence of which manifests itself in a holistic functioning. Insufficiently adequate due to the "flaws" in the development of the personality of the relationship in certain life situations are not so much a condition of external and internal conflicts, but a cause of the inability to successfully resolve these conflicts.

Despite the fact that the verbal formula is considered the main means of suggestive influence, we widely used the possibilities of non-verbal means of influence-poses, facial expressions, gestures, rate of breathing, slowingspeeding up speech, changing timbre and other ways of adjusting to unconscious reactions of the patient (unconscious at the current moment). This is one of the essential elements of "adjustment" and the subsequent "management" of the patient into a trance (hypnosis) with the purpose of therapeutic influence on him (all these factors are of great importance and these mechanisms of influence are very important when trancing the model of M. Erickson) because they greatly potentiate verbal promptings.

The process of accepting suggestion by patients is mediated through specific psychological mechanisms. The perception of suggestion includes directly perception, memorization and retarded realization, which function autonomously from the strong-willed sphere of the patient, and are identified as autogenic psychic phenomena. On the basis of modern data, it seems that acceptance of suggestion is possible only under certain psychophysiological conditions, in a state of reduced level of awareness (conscious thinking) or in the state of the so-called "trance", which is an obligatory condition. The main therapeutic value of trance is that it can save a person from harsh restrictions and thereby make it possible to restructure and reorganize the system of self-perception. Conscious, purposeful activity, as a rule, is connected with the establishment of certain mental configurations, or structures, which narrows the field of attention or concentrates it only on the signals connected with these restrictions. The literature has repeatedly confirmed the existence of a distorting process.
For example, the mood distorts knowledge in the direction of the corresponding effect; Happy subjects had happy memories and vice versa. These data indicate the presence of limitations (affective, cognitive, positional), which drastically reduces the processing of information.

Such distortions have a clinical importance, since people burdened by problems are obsessed with certain unchanging structures of information processing. Such fixation does not allow flexible adaptation to changing needs, situations and relationships; Instead, it again and again leads to the same undesirable result. Achieving trance activates the resources necessary for transformational changes, creating a degree-ming (i.e., undistorted) state of selfperception, in which new ways of existence can be discovered.

The increasing recognition of the biopsychosocial model of the disease sharpens the question of the correlation of biological (primarily pharmacological), psychological and social effects in the system of treatment of neurotic disorders. Although pharmacotherapy continues to be considered the main factor of medical and biological intervention, its direct and indirect psychotherapeutic effects are emphasized.

Pharmacotherapy was used by us according to the general principles of its application, that is, taking into account the anti-anxiety, vegetativestabilizing and sleep-regulating components in the spectrum of psychotropic activity of the drug, on the one hand, and the structure of the clinical picture, on the other. Pharmacotherapy contributed to the psychotherapeutic process through the realization of its specific biological activity and was useful in establishing contact with the patient, to strengthen the therapeutic connection, demonstrating the competence of the physician by easing the symptoms. It helped to remove barriers to effective therapeutic communication, increased the degree of freedom in studying patients' hidden psychological conflicts, helped to break down the symptomatic barriers and enhance psychological changes and integrate a new understanding.

On this basis, all patients received biological treatment, taking into account direct and indirect psychotherapeutic effects. As a base drug, antidepressants of the serotonin reuptake inhibitors group in tablets $0.01 \mathrm{~g}$ once a day were used. Some patients (at the beginning of treatment) used tranquilizers of the nonbenzodiazepine series at night or twice a day. It is characteristic that as the number of sessions of psychotherapy increased, the doses of drugs decreased and by the end of treatment were completely excluded. 


\section{References}

1. Михайлов Б. В. Роль и место психотерапии в формировании качества жизни больных с невротическими и психотическими расстройствами / Б. В. Михайлов, В. В. Чугунов, И.Н.Сарвир // Журн. психиатрии и медицинской психологии. - 2004. - № 4 (14). - С. 35-38

2. Кришталь В. В. Психосоматическая патология: генез и подходы к коррекции / В. В. Кришталь // Междунар. мед. журн. - 2007. - Т. 7, № 1. - С. 37-40.

3. Коростий В. И. Когнитивная психотерапия в лечении тревожных и депрессивных расстройств у молодых лиц с психосоматическими заболеваниями / В. И. Коростий // Медицинская психология. - 2011. - Т. 6 , № 3 (23). - С. 19-22.

4. Коростій В. І. Лікування психічних розладів тривожно-депресивного спектру серед хворих на психосоматичні розлади / В. І. Коростій // Інтегративні підходи в діагностиці та лікуванні психічних і психосоматичних хвороб // Матер. наук.-практ. міжрегіон. конф. - Вінниця: ВНМУ ім. М. І. Пирогова, 2010. - С. 52.

5. Михайлов Б. В. Комплекс психотерапевтичних заходів в лікуванні тривожних розладів / Б. В. Михайлов, Т. С. Чорна // Проблема прихильності хворих наркологічного профілю до терапії. Потреба в лікуванні і лікування за потребою: матер. наук.-практ. конф. $з$ міжнарод. участю, 8-9 квітня 2014 р., Харків. Харків, 2014. - С. 173-174.

6. Мороз С. М. Инвалидность как хроническая психотравмирующая ситуация / С. М. Мороз, Б. В. Михайлов // Архив психиатрии. - 2008. - Т. 14, № 2 (53). - C. 4-8.

7. Мороз С. М. Этапность психологопсихотерапевтической помощи инвалидам в соответствии с индивидуальной программой реабилитации / С. М. Мороз, Б. В. Михайлов // Журн. психиатрии и медицинской психологии. - 2009. - № 2 (22). - С. 114-117.

8. Психотерапія непсихотичних психічних розладів тривожно-депресивного спектра (когнітивно-реверсивний підхід) / М. В. Маркова, С. А. Бахтіярова, В. В. Бабич [та ін.] // Журн. психиатрии и медицинской психологии. - 2008. - № 2 (19). - С. 25-31.

9. Волошин П. В. Стратегія охорони психічного здоров'я населення України: сучасні можливості та перешкоди / П. В. Волошин, Н. О. Марута // Укр. вісн. психоневрології. - 2015. - Т. 23, вип. 1 (82). - С. 5-11.

10. Медична і соціальна реабілітація: підручник / В. Б. Самойленко, Н. П. Яковенко, І. О. Петряшев [та ін.]. К.: Медицина, 2013. - 463 с.

11. Медицинская реабилитация: учеб. для студентов и врачей; под общ. ред. В. Н. Сокрута, Н. И. Яблучанского. - Славянск: Ваш имидж, 2015. - 620 с.

12. Стрес і людина: медико-психологічна допомога при стресових розладах: метод. посіб.; за ред. К. Д. Бабова [та ін.]. - К.: Калита, 2014. - 92 с.

13. Chronic pain management: nonpharmacological therapies for chronic pain / K. L. Chang, R. Fillingim, R. W. Hurley [et al.] // FP Essent. - 2015. - Vol. 432. - P. 21-26.
14. Garland E. L. Treating chronic pain: the need for nonopioid options / E. L. Garland // Expert Rev. Clin. Pharmacol. - 2014. - Vol. 7 (5). - P. 545-550.

15. Шестопалова Л. Ф. Терапевтичне середовище медичного закладу психоневрологічного профілю: медико-психологічні проблеми / Л. Ф. Шестопалова // Вісн. ХНУ імені В. Н. Каразіна. Серія «Психологія». 2010. - № 913, вип. 44. - С. 188-191.

16. Васильева А. В. Исследование особенностей клинического патоморфоза невротических расстройств в новых социальных условиях в связи с выбором терапевтических стратегий// А. В.Васильева, Т. А. Караваева / Вестн. психотерапии. - 2009. - № 32. - C. 70-77.

17. Шестопалова Л. Ф. Психологія лікувального процесу: сучасні проблеми та перспективи дослідження / Л. Ф. Шестопалова // Мед. психология. - 2006. - T. 1, № 4. - С. 30-32.

18. Демченко В. А. Ефективність комплексної терапії психічно хворих у межах організаційної моделі «Інтегрована медицина» для амбулаторних загальносоматичних установ / В. А. Демченко // Мед. психологія. - 2010. - № 3 (19). - С. 62-69.

19.Кожина Г. М. Механізми формування та шляхи профілактики суїцидальної поведінкі у хворих на депресивні розлади: моногр. / Г. М. Кожина, В. І. Коростій, К. О. Зеленська. - Харків: XHMУ, 2014. - 64 c.

20. МарутаН.А.Личностьбольноговформировании резистентности невротических расстройств // $\mathrm{H}$. А. Марута, И. А. Явдак, Е. С. Череднякова / Укр. вісн. психоневрології. - 2015. - С. 115-121.

21. Шамонина Т. Г. Психологические особенности осмысления жизненного пути личности В автобиографическом, семейно-родовом и общественно-историческом аспектах: автореф. дис. на соискание ученой степени канд. психол. наук: спец. 19.00.01 «Загальна психолоія» / Т. Г. Шамонина. - М., 2012. -28 c.

22. Гришина Н. В. Ценностные ориентации личности: семья и поколение / Н. В. Гришина, С. Ю. Лавренчук // Вестн. Санкт-Петербургского университета. Серия 12 «Психология. Социология. Педагогика». - 2008. - Вып. 3. - С. 113-123.

23. Сурикова Я. А. Взаимосвязь ценностных ориентаций и значимых событий субъективной картины жизненного пути личности: автореф. дис. на соискание ученой степени канд. психол. наук: спец. 19.00.01 «Загальна психолоія» / Я. А. Сурикова. Хабаровск, 2009. - 29 с.

24. Бурлачук Л. Ф. Психология жизненных ситуаций / Л. Ф. Бурлачук, Е. Ю. Коржова. - М., 1998. - 263 с.

25. Леонтьев Д. А. Тест смысложизненных ориентаций / Д. А. Леонтьев. - М.: Смысл, 2000. - 16 с.

26. Психодіагностичні особливості когнітивних розладів серед хворих працездатного віку із соматичними захворюваннями / Г. М. Кожина, В. І. Коростій, В. Б. Михайлов [та ін.] // Мед. психология. 2012. - № 4. - С. 68-74. 